\title{
Personalien
}

\author{
Ärztegesellschaft des Kantons Bern \\ Ärztlicher Bezirksverein Bern Regio \\ Zur Aufnahme als ordentliche Mitglieder \\ haben sich angemeldet:
}

Monika Janusic, Praktische Ärztin, FMH, Falkenplatz 9, 3012 Bern

Vladimir Makaloski, Facharzt für Chirurgie spez. Gefässchirurgie, FMH, Brechbühlerstrasse 10, 3006 Bern

Zur Aufnahme als ordentliches Mitglied in leitender Funktion hat sich angemeldet:

Marc Claudio Attinger, Facharzt für Orthopädische Chirurgie und Traumatologie des Bewegungsapparates, FMH, Inselspital, Klinik und Poliklinik für Orthopädie, Freiburgstrasse 4, 3010 Bern

Einsprachen gegen diese Vorhaben müssen innerhalb 14 Tagen seit der Veröffentlichung schriftlich und begründet beim Präsidenten des Ärztlichen Bezirksvereins Bern Regio eingereicht werden. Nach Ablauf der Frist entscheidet der Vorstand über die Aufnahme des Gesuches und über die allfälligen Einsprachen.

\section{Ärztegesellschaft des Kantons Luzern}

Zur Aufnahme in unsere Gesellschaft Sektion Stadt hat sich gemeldet:

Yvonne Brun-Odermatt, Fachärztin für Kardiologie, FMH, Herzpraxis am Sonnenplatz, Gerliswilstrasse 71, 6020 Emmenbrücke

Einsprachen sind innert 20 Tagen nach der Publikation schriftlich und begründet zu richten an: Ärztegesellschaft des Kantons Luzern, Schwanenplatz 7, 6004 Luzern

\section{Ärztegesellschaft des Kantons Schwyz}

Zur Aufnahme in die Ärztegesellschaft des Kantons Schwyz hat sich angemeldet:

Helen Shang Meier, Fachärztin für Innere Medizin und Pneumologie, FMH, Hafenstrasse 8, 6440 Brunnen. Fachärztin an der Seeklinik in Brunnen.
Einsprachen gegen diese Aufnahme richten Sie schriftlich innert 20 Tagen an Dr. med. Hugo Brunner, Dorfstrasse 14, 6417 Sattel.

\section{Ärztegesellschaft Thurgau}

Zum Eintritt in die Ärztegesellschaft Thurgau hat sich gemeldet:

Claus Hoffmann, Praktischer Arzt, Oberdorfstrasse 16a, 8360 Wallenwil

\section{Preise / Prix / Premi}

\section{Vontobel-Preis 2015}

Vier junge Altersforscher werden anlässlich des 16. Gerontologietages der Universität Zürich mit dem diesjährigen Vontobel-Preis ausgezeichnet.

- Den ersten mit 15000 Franken dotierten Preis erhalten Maren Cordi, wissenschaftliche Mitarbeiterin am Institut für Komplementärmedizin an der Universität Zürich, und Björn Rasch, ehemaliger SNF-Professor der Universität Zürich mit Ruf auf den Lehrstuhl für Kognitive Biopsychologie und Methoden an der Universität Freiburg. Die beiden auf Schlafforschung spezialisierten Psychologen wiesen nach, dass Hypnose den erholsamen Tiefschlaf verlängert.

- Den zweiten Preis teilt sich Renato Frey mit Nils Ulrich und Jakob Burgstaller. Renato Frey ist Psychologe am Center for Cognitive and Decision Sciences der Universität Basel und assoziierter wissenschaftlicher Mitarbeiter des Center for Adaptive Rationality am Max PlanckInstitut für menschliche Entwicklung in Berlin. Er konnte auf originelle Weise aufzeigen, dass Senioren Entscheidungen in alltäglichen Situationen gleich gut treffen wie jüngere Personen. Nils Ulrich, Oberarzt in der Wirbelsäulenchirurgie der Universitätsklinik Balgrist, und Jakob Burgstaller, wissenschaftlicher Mitarbeiter am Horten-Zentrum für praxisorientierte Forschung und Wissenstransfer der Universität Zürich, haben die Vorgehensweise bei der Diagnose einer Verengung der Lendenwirbelsäule von über 80-jährigen Patienten geprüft. Die für diese Altersgruppe erstmals vorgelegten Ergebnisse weisen darauf hin, dass die für jüngere Patienten empfohlene Behandlung bei über 80-Jährigen das gleiche Potential hat.
Swiss Society for Infectious Diseases (SSI), Swiss Society for Hospital Hygiene (SSHH), Swiss Academic Foundation for Education in Infectious Diseases (SAFE-ID)

The Swiss Society for Infectious Diseases (SSI), The Swiss Society for Hospital Hygiene (SSHH) and the Swiss Academic Foundation for Education in Infectious Diseases (SAFE-ID) awarded 3 prizes, each in the amount of CHF 15000 .- through equal contributions by the Societies.

- In the category "Infection Control and Hospital Epidemiology» the awardee is Dr. Cristina Bellini from the Lausanne University Hospital for the work «Universal Screening and Decolonization for Control of MRSA in Nursing Homes: A Cluster Randomized Controlled Study» published in Infection Control and Hospital Epidemiology.

- In the category "Clinical Research" the awardee is Dr. Angela Huttner for the VSV Ebola Consortium from University Hospitals of Geneva (VEBCON) for the work «Phase 1 Trials of rVSV Ebola Vaccine in Africa and Europe - Preliminary Report» published in The New England Journal of Medicine.

- In the category "Basic Research in Infectious Diseases» the awardee is Prof. Roberto F. Speck from the University Hospital of Zurich, for the works «Optimization of Critical Hairpin Features Allows miRNAbased Gene Knockdown Upon Single-copy Transduction" published in the Journal of Virology, and «Lentivector Knockdown of CCR5 in Hematopoietic Stem and Progenitor Cells Confers Functional and Persistent HIV-1 Resistance in Humanized Mice» published in the Journal of Virology. 